\title{
Competence, Work Culture and Performance of Honorary Teachers in Makassar Elementary School
}

\author{
Sitti Nurbaya, Ismail Rasulong, and Muh. Nur. R
}

\begin{abstract}
We will exploration in explaining the contribution of competence to work culture; contribution of competence to teacher performance; the contribution of work culture to teacher performance; the contribution of competence through work culture to the work performance of Honorary Teachers In Makassar Elementary School is very important to do in determining the attitudes and policies of the city government towards Honorary Teachers In Makassar City. The study was conducted at Makassar Elementary School with a population of Honorary Teachers who have a Decree of limited time employment contract in 8 sub-districts in Makassar City, totaling 1,495 teachers. The total sample obtained was 317 teachers using the Slovin formula. The research hypothesis was tested using the Structural Equation Model through the help of AMOS vers. 20.0 programs. The results of the study provide evidence that the competencies possessed are proven to directly improve the work culture of honorary teachers. High competence is proven to directly be able to improve the performance of honorary teachers to a high level. Work culture directly has a significant positive effect on the performance of honorary teachers. Competence through work culture is indirectly proven to increase the work performance of Honorary Teachers in Makassar Elementary School to a higher level.
\end{abstract}

Index Terms-Competence, work culture, work performance, honorary teachers.

\section{INTRODUCTION}

Education largely determines the progress and quality of a country. Developed countries have quality education. Quality education is obtained from qualified teachers. In other words, teachers are educators who are the main key to the creation of quality education and the progress of a country. The teacher has a duty as a public servant in the world of education. The profession of a teacher must provide maximum service in the world of education to the community. In particular a teacher is required to provide professional services to students so that learning objectives are easily achieved. Teachers can be said to be professional if they have competencies and special skills in their fields.

Republic of Indonesia Law No. 14 of 2005 concerning Teachers and Lecturers said that the teacher is a professional educator where the main task is to carry out the learning process for students at the level of early childhood education

Published on March 29, 2020

S. N. Faculty of Economics, Muhammadiyah University Makassar, Indonesia. (e-mail: st.nurbaya@unismuh.ac.id)

I. R. Faculty of Economics, Muhammadiyah University Makassar, Indonesia. (e-mail: ismail.rasulong@unismuh.ac.id)

M. N. R. Faculty of Economics, Muhammadiyah University Makassar, Indonesia. (e-mail: muhnur@unismuh.ac.id)
(PAUD), basic education (DIKDAS), and secondary education (DIKMEN). An educator has a status as a professional at the PAUD, DIKDAS, and DIKMEN levels, in formal education appointed in accordance with statutory regulations (Republic of Indonesia, Law No. 14 of 2005 concerning teachers and lecturers in Article 2, 2005).

Things that affect the success or failure of education other than teachers and students, there are also other things, namely infrastructure, environment, and curriculum. Some of these things, teachers who occupy a very important position in the learning process activities in schools and by not ignoring the other supporters, the teacher as a subject that is crucial for the success of education itself. It is recognized that the teacher is the main key in the education process. Although educational facilities are complete and technologically, but if not supported by the presence of qualified teachers, it is impossible to bring up the optimal learning and learning process. Teachers as drivers of national education are a key factor in the success of education in Indonesia.

Teachers are required to give birth to generations of quality and competitiveness in all fields of science. However, the reality is not as expected, the teacher's performance still needs to be improved. Teacher performance is not optimal because the school has not implemented work culture in the school environment. The school is a formal organization and as a place of implementation or embodiment of the 1945 Constitution of the Republic of Indonesia, namely Chapter XIII about education Article 31 paragraph (1) Every citizen has the right to receive teaching, paragraph (2) The government strives and organizes an education system nationally regulated by law.

Each school will certainly be influenced by the culture of each school's organization, although the main basis for providing education is based on existing government regulations. Organizational culture in each school is a guide or guide to the behavior of people involved in the learning process of students in school. From the description above, it means that organizational culture is an assumption or statement received in an organizational group about the reaction of members to the organizational environment of the people in the organization. Likewise, organizational culture cannot be separated from work culture, but each school certainly has work culture a different in accordance with concepts that are believed to be owned by people who join in it, agreed to be implemented together.

The phenomenon that occurs in the world of education in Makassar City, especially in primary schools, most of the teachers who teach are still honorary. The number of honorary teachers who have Decree of limited time employment contract is 2,328 teachers with details of 270 
for junior high school teachers, 1,909 people for elementary school teachers, 4 people for kindergarten teachers, and 145 people for educational staff, and around 327 others who have not get a Decree of limited time employment contract because of non-linear educational qualifications and a work period that is not enough for 2 years [1].

While honorary teachers themselves are appointed by the school principal or chairman of the foundation based on emotional closeness, recommendations and kinship. The teacher's qualifications and competencies are not the only factors for accepting someone to become an honorary teacher at an elementary school but only as a supplement. The qualifications and competencies of the honorary teacher are not comparable to the learning process in elementary schools. Teachers must be able to master all subjects in elementary schools including Religious Education, Indonesian Citizenship Education, Mathematics, Natural Sciences, Social Sciences, Cultural Arts Skills, Physical and health education, and local content such as English, Regional languages, and information and communication technology [2].

The lack of honorary teacher competency has an impact on the performance of honorary teacher Makassar City. The 2015 Teacher Competency Test (UKG) results showed low teacher competency. Indonesia ranks low on students' abilities in the fields of reading, Mathematics, and Science which do not directly indicate low teacher competency. Nationally the average results of the 2015 Teacher Competency Test (UKG) in the pedagogic and professional fields are 53.02. Pedagogical competence, on average 48.94, is below the minimum competency standard (SKM), which is 55 (Maulipaksi, 2016). A total of 12,683 teachers in Makassar took the Teacher Competency Test (UKG) which consisted of 1,426 early childhood education (PAUD) levels, 5,183 elementary school level teachers, 2,643 junior high school level teachers, 1,724 senior high school level teachers teachers, 1226 Vocational High School level teachers, 171 supervisors, and special school teachers (SLB) 310 [1].

The Teacher Competency Test (UKG) Standard achieved is 55. Meanwhile, the acquisition of Teacher Competency Test (UKG) for teachers in Makassar an average of 30, 40, and 50 (Makassar City Education Office, 2015). The low Teacher Competency Test (UKG) results show that the honorary teacher competency needs to be improved and one competency needs to be added, namely the renaissance competency [1].

Renaissance competence is teacher competency that must be driven by time to improve the ability and selfactualization to the level of enlightenment, thoughts, and ideas understood by the people, and able to arouse enthusiasm for learning and change people's lives. In order to become a Renaissance teacher you have to study very hard throughout your life. Not only one discipline must be mastered, but all disciplines must be studied and studied in depth so that they can master all existing disciplines, can link, can connect, and are able to combine all dimensions of science [3].

Renaissance teachers competence are teachers who have the ability to combine two idealism, namely the idealism of thought and social idealism. The idealism of thought originates from the field of knowledge, discourse, and theory. Whereas social idealism stems from expertise and accuracy in coming into contact with the reality of humanitarian problems that are full of oppression, distortion, extortion far from justice, prosperity, and progress. Renaissance teachers are teachers who dare to fight and sacrifice for others. Dare to fight and sacrifice to give birth to a big dream to spark world change is a starting point to start a big thing. Renaissance teachers are teachers who always sow the seeds of the future, potential young people will fill the future civilization [4].

Being a Renaissance teacher, results are not important because what determines is the process that is carried out in a disciplined, responsible, analytical, and not in a hurry. Renaissance teachers feel they are not at the peak of their careers, they do not feel they are on the throne of knowledge, socially, but prefer to position themselves as servants of the community who devote their time, energy, materials and thoughts to the advancement of education. With the phenomenon that occurs in the world of education, especially in the city of Makassar, researchers argue that Law No. 14 of 2015 concerning Teachers and Lecturers includes 4 competencies (pedagogic, social, personality, and professional) that need to be added by one competency, namely the renaissance competency [4].

Work culture that cannot be applied because it is still constrained by the above phenomena. Competence that is not maximized results in the performance of honorary teachers not being maximized. Teachers do not have competence because they are not able to operate computers, teaching methods carried out in class are only lectures, are unable to implement teaching methods that are actively pleasing to students, are unable to use and process information sources from the internet, and do not master concepts. For example in science olympiad competitions, Makassar City never represented South Sulawesi Province in the event. Especially for honorary teachers in primary schools in addition to the four competencies (pedagogical, social, personality, and professional competencies) that must be possessed, one competency needs to be added, namely the renaissance competency. Renaissance competence is the competency that must be possessed by the teacher as the climax competency that must be completed by the teacher. Renaissance competence is an enlightenment competency because it is not only seen from the breadth of his knowledge and the depth of his knowledge, but also has an enlightening effect on his thinking [5].

Enlightenment that leads to awareness, repentance, a strong desire to change, and carry out an active movement to meet the future with commitment and progressive. The teacher must be able to carry out this noble task for the recovery of a dynamic and productive future. Teachers are educators and educators are people who deliberately influence others to achieve educational goals [2]. In the industrial era 4.0 where teachers are required to master at least one foreign language, master knowledge and technology, and have an entrepreneurial spirit.

The Holly Qur'an Surah Ar-Rad Verse 11 says that: For humans there are angels who always follow him in turn, in front of and behind him, they guard him by the command of Allah. Surely Allah will not change the destiny of a people 
until they themselves change it. And if God wants evil against a people, then no one can reject it; and there is no shield for them except Him (Ar-Rad ,11-13).

Based on the data and phenomena mentioned above, it is necessary to make efforts by the Makassar City Government to improve teacher performance. Teacher performance improvement ranging from basic education to secondary education both public and private to continue to be improved. Improving teacher performance must synergize with the implementation of a work culture that affects high competence. This means that teacher competencies are expected to be improved through pedagogical, personality, social, professional and renaissance competencies in influencing their performance.

Gap theory which shows that competence influences teacher performance as stated in lost theory [6] that the quality of education will be lost if performance is not improved. Brain theory [7], states that the brain of human resources lies in the resulting performance. Building the human resource brain begins with improving competence. It is seen that the gap research phenomenon shows that teacher competencies in the form of pedagogical, personality, social, professional and renaissance competencies that are not properly implemented, make students in adopting the knowledge taught by teachers difficult to accept, given teacher's competence has not produced facilities for students to accept and carry out the learning process. Teachers as social beings always interact with each other both with the principal as a leader, teacher friends as peers and students as students often lead to gaps or miscommunication trinkets (miscommunication), there tends to be individualism often indicated by the principal and Teachers, this is because of the lack of activity, please help in carrying out the vision, mission and goals of the school, neglected even often lead to conflict that does not lead to mutual respect.

The work performance to be achieved in improving the quality of education, while this research relates to the application of a maximum work culture in improving teacher performance. The performance gain achieved is inseparable from the contribution of facilities, motivation, culture and work capacity improvements that determine the occurrence of performance strengthening to produce an achievement in improving human resources [8]. This means that the research conducted by researchers is different because this research is not research on companies but on educational institutions that have different characteristics of implementation of performance [9]. That in order to achieve good performance in obtaining good work in quantity, in quality, efficiently and effectively in educational institutions it is necessary to have a work culture that is supported by competencies for the realization of a good teaching and learning process that has an effect on improving teacher performance.

\section{LITERATURE REVIEW AND HYPOTHESIS}

In this study, there were three observed variables consisting of one exogenous variable and two endogenous variables. The exogenous variable in this study is competence. While endogenous variables are intervening variables, namely work culture and the dependent variable, namely teacher performance.

\section{A. Competence}

Self competence theory is suggest that a person's self competence can be known from his pedagogical, professional, personality and social abilities [10,11].

$\mathrm{H}_{1} \rightarrow$ Competence has a positive effect on the work culture of elementary schools in Makassar City.

$\mathrm{H}_{2} \rightarrow$ Competence has a positive effect on honorary teachers performance of elementary school in Makassar City

$\mathrm{H}_{3} \rightarrow$ Competence through work culture has a positive effect on honorary teachers performance of elementary school in Makassar City

\section{B. Work culture}

Work culture is an indication of the behavior of people who play a role in the learning process of students. Work culture is an implied set of assumptions that an organization has for granted that the organization holds and determines how to look, think, and react to its environment $[12,13]$. Teacher performance that the quality of education will lost if performance is not improved [6]. Brain theory is explained that the brain of human resources lies in the resulting performance $[7,14]$.

$\mathrm{H}_{4} \rightarrow$ Work culture has a positive effect on honorary teachers performance of elementary school in Makassar City

\section{RESEARCH METHODS}

This study was designed to answer the problem formulation and research objectives and test the hypothesis Location of the research was conducted at the Elementary School in Makassar City as the object of research to see the effect of competence on the work culture and performance of honorary teachers of Primary Schools in Makassar City. Quantitative research and qualitative research consists of primary data and secondary data. Data collection techniques (instruments) use observation techniques, questionnaires, interviews and documentation.

The population in this study were all elementary school honorary teachers in Makassar City, amounting to 1,909 people, given that Makassar City is very large, limited by the population in 8 (eight) districts with 1,495 honorary teachers. The sample is a collection of sampling units selected from a sampling frame. Research that takes samples from the population and a questionnaire as a primary data collection tool. Using the Slovin formula obtained from a sample of 317 respondents. Descriptive statistical analysis techniques and Structural Equation Modeling (SEM) analysis are data analysis techniques used in explaining the phenomena in this study.

\section{RESUlts}

Analysis of the results of the study (Analysis of Moment Structure), using the AMOS vers. 20.0 program using the structural equation model (SEM) with confirmatory factor analysis (CFA). Critical ratio (CR) functions to see the predictive power of observational variables both at the individual level and at the construct level.

These dimensions will be said to be useful for predicting constructs or latent variables if the critical ratio shows significant. The latent variable (construct) of this study 
consisted of competence in work culture and performance of elementary school honorary teachers. Fit model indicators will be obtained using the structural equation model from AMOS. The value of the critical ratio (CR) in the regression weight with a minimum of 2.0 in absolute value as the benchmarks used in testing each hypothesis.

There are 4 criteria used to test whether the proposed model is compatible with the data or not. The four criteria of the fit model: (a) RMSEA (Root Mean Square Error of Approximation) is low. (b) incremental fit above 0.90, namely GFI (goodness of fit index), Adjusted GFI (AGFI), Tucker Lewis Index (TLI), The Minimum Sample Discrepancy Function (CMIN) divided by its degree of freedom (DF) and Comparative Fit Index (CFI), (c) degree of freedom (degree of freedom) must be positive and (d). non-significant Chi-square requirements $(\mathrm{p} \geq 0.05)$ and above conservatives accepted $(p=0.10)[15,16]$.

To examine the variables that define a construct that cannot be measured directlyused Confirmatory Factor Analysis is. Exogenousvariables and endogenous variables as model testing variables. Variables whose values are determined outside the model are exogenous variables. While the variable whose value is determined through the equation or from the relationship model formed is an endogenous variable. Exogenous variable groups are measures of competence while endogenous variables are work culture and performance. Analysis of the variable construct model was carried out in six stages. Stage 1 to stage 5 shows the construction model that does not meet the criteria goodness of fit indices with the chi-square value is still large and it seems that some criteria do not match thevalue cut-off specified, so the model is modified by correlating the error indicators according to the instructions from modification indices.

The evaluation results the model shows that from the eight criteria of goodness of fit indices, the chi-square value has decreased with a fixed value of 264,253, although there are still criteria that do not match thevalue cut-off. More details Phase 6 model test results were evaluated based on goodness of fit indices in Table 1 with the model criteria and their critical values that have data suitability presented.

TABLE I: GOODNESS OF FIT

\begin{tabular}{cccc}
\hline Criterion & Cut-off Value & Results & Remarks \\
\hline Chi_Square & $\leq$ small & 264.253 & Fulfilled \\
\hline Probability & $\geq 0.05$ & 0.117 & Fulfilled \\
\hline RMSEA & $\leq 0.08$ & 0.022 & Fulfilled \\
\hline RMR & $\leq 0.05$ & 0.018 & Fulfilled \\
\hline GFI & $\geq 0.90$ & 0.916 & Fulfilled \\
\hline AGFI & $\geq 0.90$ & 0.885 & Not fulfilled \\
\hline TLI & $\geq 0.94$ & 0.989 & Fulfilled \\
\hline CFI & $\geq 0.94$ & 0.986 & Fulfilled \\
\hline & DF & & 238 \\
\hline
\end{tabular}

The results of the model evaluation show that not all of the eight goodness of fit indices criteria are said to meet the criteria cut off value, namely the AGFI value. In this analysis has passed through 6 stages of model modification, then stage 6 as the final stage shows that there are seven goodness of fit indices criteria that have met the criteria or according to the cut-off value, so the model can be said to be in accordance with the criteria goodness of fit indices to be analyzed. Empirical models proposed in this study can be tested on hypotheses through testing the path coefficient on the structural equation model. Table 2 is testing the hypothesis by looking at the value of $p$-value, if the value of p-value is less than 0.05 then the relationship between variables is significant. Table 2 also explains the direct effect, which means there is a positive between indirect effect variables means that there is a positive between variables, and the total effect (total effect), which is the accumulation of the sum of the values of direct and indirect effect. The test results can be seen in the following table:

TABLE II: GOODNESS OF FIT

\begin{tabular}{|c|c|c|c|c|}
\hline \multicolumn{5}{|c|}{ LE II: GOODNESS OF FIT } \\
\hline exogenous & Intervening & endogenous & Probability & Remarks \\
\hline $\begin{array}{c}\text { Competence } \\
\text { (COM) }\end{array}$ & - & $\begin{array}{l}\text { Work culture } \\
\text { (WOC) }\end{array}$ & 0.000 & Accepted \\
\hline $\begin{array}{c}\text { Competence } \\
\text { (COM) }\end{array}$ & - & $\begin{array}{c}\text { Teacher } \\
\text { Performance } \\
\text { (TP) }\end{array}$ & 0.001 & Accepted \\
\hline $\begin{array}{c}\text { Work } \\
\text { culture } \\
\text { (WOC) }\end{array}$ & - & $\begin{array}{c}\text { Teacher } \\
\text { Performance } \\
\text { (TP) }\end{array}$ & 0.000 & Accepted \\
\hline $\begin{array}{l}\text { Competence } \\
\text { (COM) }\end{array}$ & $\begin{array}{l}\text { Work } \\
\text { culture } \\
\text { (WOC) }\end{array}$ & $\begin{array}{c}\text { Teacher } \\
\text { Performance } \\
\text { (TP) }\end{array}$ & 0.001 & Accepted \\
\hline
\end{tabular}

All of the proposed models, two direct paths and two indirect pathways were hypothesized, all of which were seen to have a positive and significant effect. The interpretation of the results can be explained as follows: (1) Competency directly has a positive and significant effect on work culture with a value of $p=0.000<0.05$ and a coefficient value of 0.267 , meaning that the competency of the honorary elementary school teacher is good and correlates in showing work culture the good one; (2) competence directly has a positive and significant effect on teacher performance with $\mathrm{p}$ $=0.001<0.05$ and coefficient value of 0.171 , meaning that the competencies of elementary school honorary teachers make a correlated contribution to improving teacher performance; (3) work culture directly has a positive and significant effect on teacher performance with a value of $\mathrm{p}=$ $0.000<0.05$ and a coefficient value of 0.586 , meaning that the creation of work culture that is applied by the teacher contributes a correlated contribution to the improvement of teacher performance; (4) competence through work culture has a positive and significant on teacher performance with indirect effect coefficient of 0.156 with a significance level of $p=0.001<0.05$, proving that indirectly the competency that is owned is actualized according to work culture, thus providing contribution to improving the performance of elementary honorary teachers.

\section{CONCLUSION}

Competence was proven to be able to improve the work culture of honorary teachers in accordance with the abilities of the teacher in carrying out their duties as educators and instructors to have the ability to accumulate pendagogik, personality, socialization, professional and renaissance. in 
itself to develop a work culture in accordance with the level of adaptation and external and internal integration of the honorary teacher.

Competence is proven to be able to directly improve the performance of honorary teachers, which is shown through the high level of teacher's ability to develop and accumulate potentials that are owned both pedagogically, personality, socialization, professional and renaissance to work competently in improving their performance according to quality, quantity, and efficiency and effective in teaching in schools.

Work culture is proven to be able to directly improve the performance of honorary teachers in adopting and integrating externally and internally all educational and teaching activities in schools to their level of quality in teaching, quantity to students taught, efficient in timeliness of teaching and effective in learning material provided

Competence through work culture as a mediating variable effect is proven to be able to improve the performance of honorary teachers, this is proven to be obtained by the level of teacher competence in the form of pedagogic, personality, socialization, professional and renaissance and has been actualized through work culture in adaptation and integration both external and internally in improving the performance of honorary teachers.

\section{REFERENCES}

[1] Makassar Education Office (2017). The report of honorary teachers who have Decree of limited time employment contract

[2] Asmani, Jamal Ma'mur. (2009). "7 Fun and Professional Teacher Competencies". Jogjakarta Power Books

[3] Ehrhart, P. M., \& Furlong, B. (1993). The renaissance nurse: permeating clinical competence with the humanities. Nurse educator, 18(3), 22-24.

[4] Tracz, S. M. (2013). Effectiveness of Teacher Education Programs: A Descriptive Aggregation of Supervisor Ratings of Teachers Trained by the Renaissance Group (TRG) and the Teacher Education Council of State Colleges and Universities (TECSCU) Institutions. Educational Renaissance, 1(2), 63-82.

[5] Robbins, S. P., \& Judge, T. (2003). Essentials of organizational behavior (Vol. 7). Upper Saddle River, NJ: Prentice Hall.

[6] Gagne, R, (2002). The Learning Media to Smart People. Published by West Publishing Company, New York

[7] Ersü, E., \& Tolle, H. (1984). A new concept for learning control inspired by brain theory. IFAC Proceedings Volumes, 17(2), 10391044.

[8] Robbins, S. P., \& Coulter, M. (2007). Principles of management. Translated by Seyyed Mohammad Arabi and Mohammed Ali Hamid Rafiee and Behrouz Asrari Ershad, Fourth Edition, Tehran: Office of Cultural Studies.

[9] Shakanawi, Miako. (2012). The Strength of the Performance Improvement through Work Commitment, Motivation, Culture and Work Ability towards Increasing the Quality of Human Resources in Toyota Inc. Japan

[10] Ryan, R. M., \& Deci, E. L. (2000). Self-determination theory and the facilitation of intrinsic motivation, social development, and wellbeing. American Psychologist, 55, 68-78.

[11] Tafarodi, Romin W., and William B. Swann Jr. "Self-linking and selfcompetence as dimensions of global self-esteem: initial validation of a measure." Journal of personality assessment 65.2 (1995): 322-342.

[12] Kreitner, Robert \& Angelo Kinichi. (2009). Organizational Behavior, USA D Irwin Inc. Third Edition

[13] Reynaldi, R., Ridjal, S., \& Sjahruddin, H. (2019). The Role Of Organizational Citizenship Behavior In Work Performance: An Investigation Based On Hotel Employee Survey. European Journal of Business and Management Research, 4(6).

[14] Idris, M. H., Jamali, H., \& Sjahruddin, H. (2019). Investigating the moderating role of knowledge: The relationship between auditor's experience and ethical judgment. Advances in Social Sciences Research Journal, 6(2)
[15] Hasanuddin, R., \& Sjahruddin, H. (2017). The structure of emotional intelligence, spiritual intelligence and its relationship with work enthusiasm and auditor performance. Structure, 3(1). 